\title{
Commentary on "Sulla Fina Anatomia del Cervelletto Umano. Archivio Italiano per le Malatie Nervose 11:90-107." (English Title: On the Fine Anatomy of the Human Cerebellum)
}

\author{
Paolo Mazzarello • Duane E. Haines • \\ Mario-Ubaldo Manto
}

Published online: 4 February 2012

(C) Springer Science+Business Media, LLC 2012

Golgi's paper describes the fundamental cytoarchitecture of the entire cerebellum. The whole of paragraph IV of the article is dedicated to the granule cells layer which, in his subdivision, was located between the molecular layer, or external cortical layer, and the inner layer of white matter containing the myelinated fibres.

He stated that [3]:

[...] always in the granular layer, with the silver nitrate method, I was able to verify not only the beautiful characteristics of the nerve cell that lay within (characteristics that some have denies) but I was also able to depict their exact dimensions, shapes, positions and ramifications $[\ldots]$.

P. Mazzarello $(\bowtie)$

Historical Museum of the University and Department of

Experimental Medicine, University of Pavia,

Pavia, Italy

e-mail: paolo.mazzarello@unipv.it

D. E. Haines

Department of Anatomy,

University of Mississippi Medical Center,

2500 North State Street,

Jackson, MS 39216, USA

e-mail: dhaines@umc.edu

M.-U. Manto

FNRS-Laboratorie de Neurologie Expérimentale,

Université Libre de Bruxelles, ULB-Erasme,

Route de Lennik 808,

1070 Brussels, Belgium

e-mail: mmanto@ulb.ac.be
Before Golgi's study on cerebellum, there were contradictory ideas on the nature of the granule cell layer. Some histologists regarded the cells contained at this level, as "connective" cells (i.e. glial cells). On the basis of the application of the black reaction, which quite easily allowed a differentiation between nerve and glial cells, Golgi was very determined to affirm that "the so-called granules must be generally considered as small nerve cells provided with three, four, five, and sometimes six processes, usually ramified" and that only one of these processes "should be essentially considered a nerve prolongation" (axon) (Fig. 1). The constant presence of a single ramified nervous prolongation (i.e. of a single axon) for every single nerve cell, later confirmed by Golgi as being applicable to all the regions of the central nervous system, is one of his most enduring contributions to neuroscience.

In the external layer of the cerebellar cortex, Golgi discovered bundles of fibres which "run parallel to each other and, in most cases, are of considerable length, many of them running around an entire circumvolution" (Fig. 1). Golgi was able to observe that these fibres, now known as parallel fibres, "could be considered as originating from the granule layer" but was unable to fully trace the axons of the granule cells and so his research failed to reveal that the axons in fact ascend toward the most external region of the cortex and then bifurcates in the shape of a $\mathrm{T}$, giving origin to the parallel fibres. This was one of the first important discoveries of Santiago Ramón y Cajal which was made with the aid of the black reaction in 1888 [8].

Furthermore, Golgi described two kinds of "big nerve cells" in the granular layer - the first were "long and narrow cells irregularly fusiform, with a maximum diameter parallel to the surface of the circumvolution" and the others were "irregularly 
Fig. 1 One of Golgi's drawings of granule cells and immediately adjacent Purkinje cells. Although his 1874 paper reprinted here did not contain any illustrations, this drawing from his Opera Omnia (Collected Work), Hoepli, Milano, volume I, Table 19 , is certainly representative of what he saw in his earlier preparations

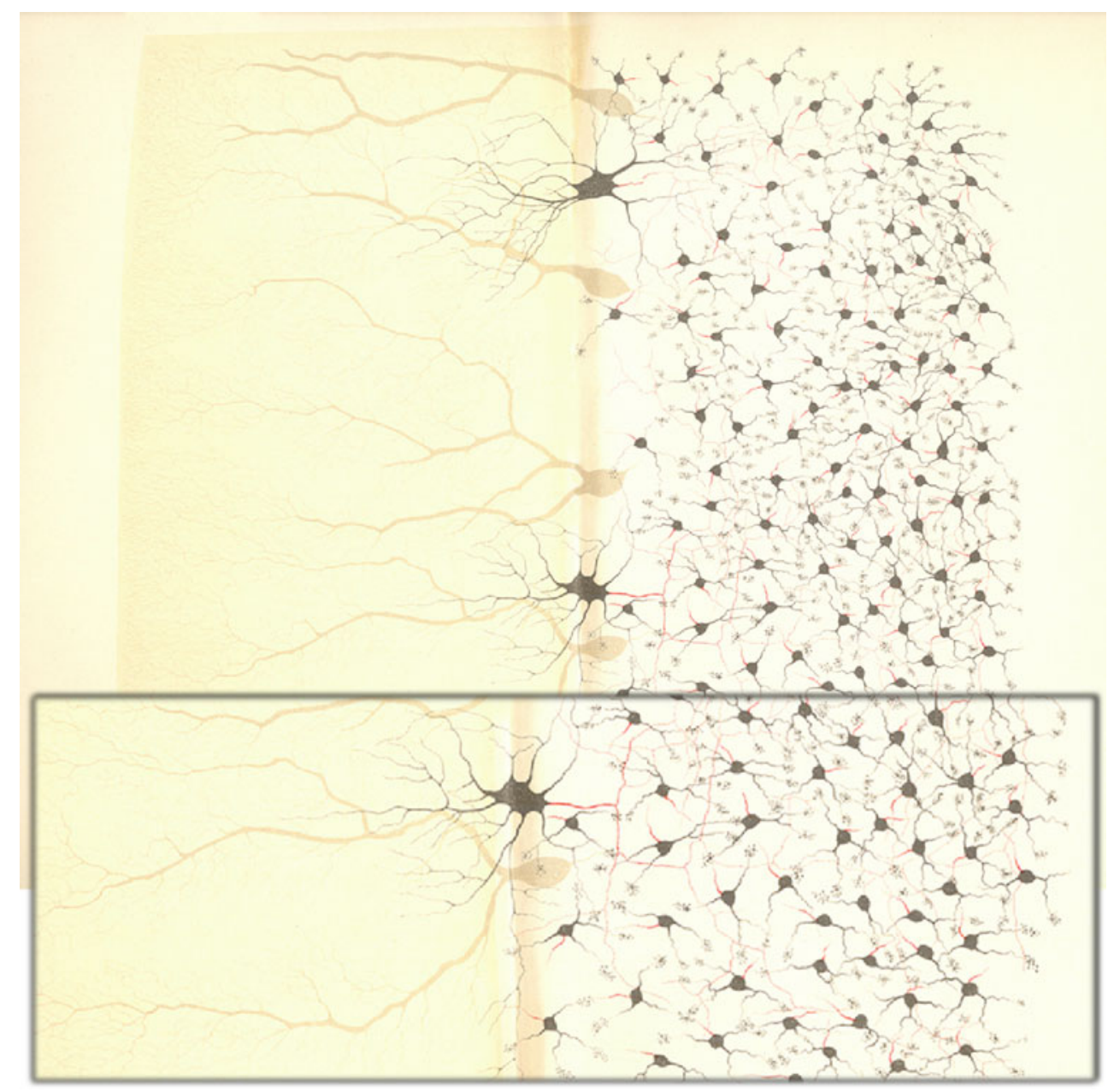

round or polygonal cells, with round corners, quite laterally flattened, similar to some others lying in the deep layers of cerebral cortex, ${ }^{1}$ with the maximum diameter transversally placed in respect to the direction of granular layer, and so perpendicular to the surface of the circumvolution. Both these types have a large number of prolongations [...]".

Then Golgi added:

More than once from a single nervous prolongation of one of these cells, I saw the formation, cause of the fine and repeated subdivisions in all directions, of a complicated filament's interlacement, going from the periphery of the granular layer in both lateral directions, widespread for more than $200 \mu \mathrm{m}$.

For what concerns their position, we can say that these gangliar cells are present at the same level at the periphery of the granular layer, close to Purkinje cells, in the middle of the layer, and also in the deepest parts; sometime it is possible to see some of them in the

\footnotetext{
${ }^{1}$ Golgi did, indeed, use the term "...cerebral cortex..." (corteccia cerebrale) on page 100 of his paper, first row from the bottom.
}

medullary rays, where the nervous fibres are still parallel or they have just started diverging.

The first type of these "big nerve cells" probably corresponds to what was subsequently known as the Lugaro cell (named after the Italian psychiatrist Ernesto Lugaro, 1870 1940, who provided a detailed description of these structures), whereas the second is the cell that now bears Golgi's name- the "Golgi cell".

Golgi's description of the mode of connexion of the fibres in the granular layer, which was heavily conditioned by the idea of a diffuse nervous plexus distributed inside the central nervous system, was less clear. In fact he described the presence, in this layer, an extremely complicated net of nervous fibres though their mode of formation was not very clear to him. He was, however, going to go on to argue that this diffuse nervous net formed by the anastomosis (or the tight interlacing) of the nervous prolongation of the nerve cells functioned as an important organ of communication between the different region of the nervous system. In 1874, at the time of the publication of the article, this theory had not yet been fully developed, but it is clear that the idea was evolving and already at work in Golgi's mind. 


\section{References}

1. Golgi C. Sulla struttura della sostanza grigia del cervello (Comunicazione preventiva). Gazzetta Med Ital-Lombardia. 1873;33:244-6.

2. Golgi C. Sulla fina anatomia del cervelletto umano. Rend R Ist Lombardo Sci Lett. 1874;7(serie 2):69-72.

3. Golgi C. Sulla fina anatomia del cervelletto umano. Arch Ital Malatie Nervose. 1874;11:90-107.

4. Golgi C. Sulle alterazioni degli organi centrali nervosi in un caso di corea gesticolatoria associata ad alienazione mentale. Riv Clin. 1874;4(serie 2):361-77.
5. Mazzarello P. Golgi. New York: Oxford University Press; 2010.

6. Mazzarello P. Cesare Lombroso: an anthropologist between evolution and degeneration. Funct Neurol. 2011;26:97-101.

7. Mazzarello P, Calligaro AL, Calligaro A. Giulio Bizzozero: a pioneer of cell biology. Nat Rev Mol Cell Biol. 2001;2:77681.

8. Ramón y Cajal S. Sobre las fibras nerviosas de la capa molecular del cerebelo. Rev Trimest Histol Norm Patol. 1888;1: 33-49.

9. Shepherd GM, Greer CA, Mazzarello P, Sassoè-Pognetto M. The first images of nerve cells: Golgi on the olfactory bulb 1875. Brain Res Rev. 2011;66:92-105. 